\title{
Effect of top cover tilt angle with ground surface on productivity of basin type solar distillation unit
}

\author{
Hosney Ara Begum*1, M. Abu Yousuf, K Siddique-e Rabbani \\ Department of Biomedical Physics \& Technology, Dhaka University, Dhaka \\ ${ }^{1}$ Presently at: Industrial Physics Division, BCSIR Laboratories Dhaka \\ hosneyara@gmail.com, aybabu@gmail.com, rabbani@du.ac.bd \\ * Corresponding author
}

[Received 11 September, 2017, Accepted, 14 November, 2018]

\begin{abstract}
Basin type solar stills were made with two types of top cover, transparent PVC sheet and another with glass sheet. A soaked black towel was at the base which was heated through green-house effect and contributed to the water for distillation. Productivity of these two basin type solar stills were studied at different tilt angles of the top transparent cover with ground surface $\left(13^{\circ}, 23^{\circ}\right.$ and $\left.35^{\circ}\right)$. The average amount of distilled water produced increased with the tilt angles for both types of cover materials, that for glass being much higher than that for PVC cover.
\end{abstract}

Key words: Solar water heater, tilt angle, basin type solar still, desalination, safe drinking water.

\section{INTRODUCTION}

Safe drinking water is a basic necessity. In our Earth approximately $70 \%$ is water and $30 \%$ is land. Only $1 \%$ of total water is fresh or potable water others are saline water or contaminated [Bendfeld et al, 1998].

In the coastal region of Bangladesh, most of the available sources of drinking water have high salinity. In various places such as in the hill tracts or in the plain lands, people lack safe drinking water because indigenous sources of water became contaminated by heavy metals or by human created waste. Arsenic contamination of groundwater in certain areas of Bangladesh has reached alarming conditions. Besides, during natural disaster like flood, safe drinking water becomes a scarce resource. As a result millions of people suffer from saline or unsafe drinking water [Islam et al, 2013].

Bangladesh is a tropical country and future of solar energy in Bangladesh is very bright. We can successfully use solar energy for operating basin type solar still for most of the period when 
there is no rain. One can also use solar energy for distillation of saline or brackish water for the fulfillment of demand of safe drinking water especially coastal and rural people [Rahman et al 1997, Rahman et al 2001, Khan et al 2008].

The aim of the present work was to develop low cost solar distillation units (still) for individual families, with as much output as possible. We used both plastics and glass for the transparent cover. The present work was taken up to study the effect of the tilt angle of the cover of a basin type solar still with these two types of transparent cover materials.

\section{MATERIALS AND METHODS}

To design solar power desalination units, the main considerations were easy availability of materials, cost, efficiency of the units, ease of construction and ease of maintenance.

Two designs of low cost basin type solar distillation units were studied with the tilt of the cover varied. One design used a transparent PVC cover while the other used a glass cover. The base and side walls of the basin were constructed using polystyrene foam blocks attached by glue and strengthened through piercing thin spikes (bamboo tooth picks). The base was covered with a black PVC sticker to make a water holding trough. A black towel with thick elongated fibers was laid on the base. The towel was fully soaked by water to be treated. The idea of using the towel was to increase the surface area available for evaporation of water through its dangling fibres. Digital thermometers and humidity measuring sensors were fixed inside the chamber. Brackish or saline water inlet port, washout port and distilled water collection ports were provided. A provision was made for continuous supply of salt water. Finally the top cover, transparent PVC sheet or glass sheet as appropriate, were mounted and sealed using silicone sealant. The devices are shown in Figures 1 and 2. The exposure area of the devices was about $0.5 \mathrm{~m}^{2}$ each.

For the study, additional mounting supports were used to set up the devices such that the top covers made $13^{\circ}, 23^{\circ}$ and $35^{\circ}$ with the horizontal plane respectively, on different days with similar sunshine and weather conditions. The study was performed on several days in March, when the sky remained reasonably clear with similar sunshine on consecutive days. 

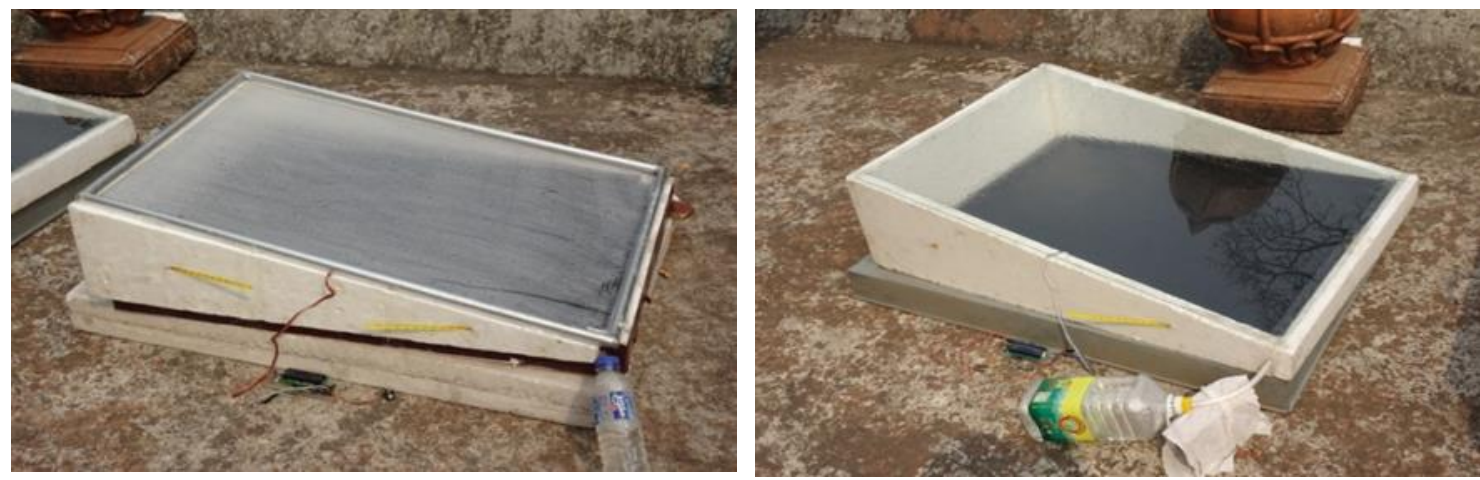

Figure 1: Basin type solar still with transparent PVC sheet cover (left) and glass sheet cover (right).

The experiment was carried out with the following steps.

i) At the first step of operation, the top surface of the solar stills were cleaned. The stills were placed facing south so that these can get the maximum amount of sunshine throughout the day. All the ports were sealed except for the water output port. The thermometer and humidity meters were checked to ensure their proper operation.

ii) The towels on the base of each devices were soaked in 2 litres of salt water. Another 5 liters of salt water was kept in a jar to provide a continuous controlled supply of water into the system using a medical saline set. The jar could be refilled when required.

iii) Initial readings of the temperature and humidity measuring meters for the inside of the chambers together with that of environment were recorded.

iv) Solar radiation was allowed to heat the inside of the basin through 'Green House Effect', raising the temperature of the water.

v) The water evaporated which then cooled, condensed and formed droplets underneath the top cover. This heating effect produced a circulation of water vapour and air inside the still.

vi) Under the top cover, water vapour condensed and accumulated to form droplets which then trickled downwards towards the collection trough because of the inclination of the top cover. From the collection trough, the distilled water flowed into a collection container through the outlet port. 
vii) After collection at the end of the day, the total distilled water output was measured. The outputs of the different stills were then compared.

viii) The stills were exposed to sunshine from 10:00 am to 3:00 pm (5 hours per day) during March when the sky remains clear.

\section{RESULTS AND OBSERVATIONS}

The experimental data of the basin type solar stills at different tilt angles are given in the tables below. Table 1 shows the amount of distillate from basin type distillers, with both transparent PVC sheet covered and glass sheet covered stills, set at a tilt angle of $13^{\circ}$ with the horizontal, on days indicated in the table over a time duration of 5 hours from 10:00 hours to 15:00 hours. The average of the distillate collected over the specified days is also shown with calculated output on the basis of solar ray incidence on a surface area of $1 \mathrm{~m}^{2}$.

Table 1: Amount of distillate from basin type distillers (Tilt angle $13^{\circ}$ )

\begin{tabular}{|c|c|c|c|c|c|}
\hline $\begin{array}{c}\text { Number of } \\
\text { Experiment }\end{array}$ & Date & $\begin{array}{c}\text { For } \\
\text { transparent } \\
\text { PVC sheet } \\
\text { cover }(\mathrm{ml})\end{array}$ & $\begin{array}{c}\text { For Glass } \\
\text { cover } \\
(\mathrm{ml})\end{array}$ & $\begin{array}{c}\text { Max. ambient } \\
\text { temperature } \\
{ }^{\circ} \mathrm{C}\end{array}$ & $\begin{array}{c}\text { Max. } \\
\text { ambient } \\
\text { humidity, } \\
\%\end{array}$ \\
\hline 1 & 03.03 .2015 & 440 & 1170 & 33.6 & 56 \\
\hline 2 & 06.03 .2015 & 500 & 1150 & 35.0 & 55 \\
\hline 3 & 07.03 .2015 & 538 & 1200 & 36.0 & 55 \\
\hline $\begin{array}{c}\text { Average distillate /day } \\
\left(0.5 \mathrm{~m}^{2}\right)\end{array}$ & 493 & 1173 & & \\
\hline $\begin{array}{c}\text { Average production, } \\
\left.\mathrm{ml} / \mathrm{m}^{2} / \text { day(calculated }\right)\end{array}$ & & 986 & 2346 & & \\
\hline
\end{tabular}

Amount of distillate from the two basin type distillers (transparent PVC sheet covered and glass sheet covered distillers), set at a tilt angle of $23^{\circ}$ with the horizontal, on days indicated in the table over a time duration of 5 hours (10:00 hours to 15:00 hours) are given in Table 2 . The average volume of the distillate collected over the specified days is also given with calculated output per square meter of incidence surface area. 
Table 2: Amount of distillate from basin type distillers (Tilt angle $23^{\circ}$ )

\begin{tabular}{|c|c|c|c|c|c|}
\hline $\begin{array}{c}\text { Number of } \\
\text { Experiment }\end{array}$ & Date & $\begin{array}{c}\text { For } \\
\text { transparent } \\
\text { PVC sheet } \\
\text { cover }(\mathrm{ml})\end{array}$ & $\begin{array}{c}\text { For Glass } \\
\text { cover } \\
(\mathrm{ml})\end{array}$ & $\begin{array}{c}\text { Maximum } \\
\text { ambient } \\
\text { temperature, } \\
{ }^{\circ} \mathrm{C}\end{array}$ & $\begin{array}{c}\text { Maximum } \\
\text { ambient } \\
\text { humidity, \% }\end{array}$ \\
\hline 1 & 08.03 .2015 & 680 & 1450 & 35.6 & 53 \\
\hline 2 & 09.03 .2015 & 680 & 1400 & 35.0 & 50 \\
\hline 3 & 13.03 .2015 & 685 & 1500 & 35.8 & 55 \\
\hline $\begin{array}{l}\text { Total distillate } \\
\left(0.5 \mathrm{~m}^{2}\right)\end{array}$ & & 2045 & 4350 & & \\
\hline $\begin{array}{l}\text { Average production, } \\
\mathrm{ml} / \mathrm{m}^{2} / \text { day(calculated) }\end{array}$ & & 682 & 1450 & & \\
\hline
\end{tabular}

Table 3: Amount of distillate from basin type distillers (Tilt angle $35^{\circ}$ )

\begin{tabular}{|c|c|c|c|c|c|}
\hline $\begin{array}{c}\text { Number of } \\
\text { Experiment }\end{array}$ & Date & $\begin{array}{c}\text { For } \\
\text { transparent } \\
\text { PVC sheet } \\
\text { cover }(\mathrm{ml})\end{array}$ & $\begin{array}{c}\text { For Glass } \\
\text { cover } \\
(\mathrm{ml})\end{array}$ & $\begin{array}{c}\text { Maximum } \\
\text { ambient } \\
\text { temperature, }{ }^{\circ} \mathrm{C}\end{array}$ & $\begin{array}{c}\text { Maximum } \\
\text { ambient } \\
\text { humidity, } \%\end{array}$ \\
\hline 1 & 14.03 .2015 & 750 & 1780 & 32.6 & 52 \\
\hline 2 & 15.03 .2015 & 780 & 1870 & 31.0 & 52 \\
\hline 3 & 16.03 .2015 & 785 & 1887 & 35.0 & 51 \\
\hline $\begin{array}{c}\text { Total distillate } \\
\left(0.5 \mathrm{~m}^{2}\right)\end{array}$ & 2315 & 5537 & & \\
\hline $\begin{array}{c}\text { Average production, } \\
\left.\mathrm{ml} / \mathrm{m}^{2} / \text { day(calculated }\right)\end{array}$ & & 1544 & 3692 & & \\
\hline
\end{tabular}

Table 3 shows the total distillate obtained in a day from the solar power basin type distillers with Transparent PVC sheet cover and glass sheet covered when the inclination angle of solar ray incidence surface is $35^{\circ}$. From the above table, it is observed that the average distillate obtained from the solar power basin type distiller with transparent PVC sheet cover is 772 $\mathrm{ml} /$ day and that with glass cover is $1846 \mathrm{ml} /$ day. The corresponding calculated values for 1square meter area are $1544 \mathrm{ml} / \mathrm{m}^{2} /$ day and $3692 \mathrm{ml} / \mathrm{m}^{2} /$ day respectively.

From the above tables, it may be observed that, the amount of distillate produced from glass covered distiller is more than the amount produced by the transparent PVC sheet covered 
distiller. Because, properties of glass sheet are better for this purpose than transparent PVC sheet.

Also from Figure 1 (left), it is observed that surface of transparent PVC sheet is not clear and drop of water is attached with the inner surface of the sheet. As a result these droplets of water are causing barrier to pass the solar energy inside the basin chamber and thus evaporation activity of water within the solar still is lower in comparison to that of glass sheet covered solar still (Figure 1, right) which has also been found in a previous work [Begum et al, 2016].

A comparison of the performances of all the different configurations of the basin type solar power still studied in the present work is given in Table 4. It can be seen that the distillate volume increased with the tilt angle to $35^{\circ}$ measured.

Table 4: Comparative performance (Average production, $\mathrm{ml} / \mathrm{m}^{2} /$ day) of the two types of basin type solar distiller with different tilt angles of the top cover.

\begin{tabular}{|l|c|c|c|}
\hline Cover type & Tilt: $13^{0}$ & Tilt: $23^{0}$ & Tilt: $35^{0}$ \\
\hline PVC & 986 & 1364 & 1544 \\
\hline Relative volumes & 1 & 1.38 & 1.57 \\
\hline Glass & 2346 & 2900 & 3692 \\
\hline Relative volumes & 1 & 1.24 & 1.57 \\
\hline
\end{tabular}

\section{DISCUSSION}

The research work deals with a comparative study of basin type desalination units covered by glass sheet and transparent PVC sheet placed at different tilt angles. The units are prepared indigenously and aim of the present work was to compare the productivity of the units at different tilt angles. The exposed area of the two stills were $0.5 \mathrm{~m}^{2}$. For each, the average production is also shown per $\mathrm{m}^{2}$ of exposed area.

From the comparative data given in Table 4, one can compare the productivity of all the different configurations of the basin type distillers. From the information given in this table one can see that, productivity of solar power still with both transparent PVC sheet cover and glass cover increases with the tilt angle between the measured range of $13^{\circ}$ and $35^{\circ}$. As expected, the output is less for PVC cover compared to that for glass cover as was presented earlier [Begum et al, 2016]. 
The increase with the inclination of the top cover is expected since the drops get better chances of trickling down because of gravity. However, if the inclination is further increased, a point may come when the droplets will fall within the still, before it reaches the collection trough, which will reduce the output as well. Therefore, an optimum tilt angle may be expected, but the present study did not go beyond $35^{\circ}$.

\section{ACKNOWLEDGMENT}

One of the authors (HAB) would like to thank Ministry of Science and Technology, Government of the People's Republic of Bangladesh for offering Bangabandhu Fellowship on Science and ICT for this work. The authors would also like to thank the International Science Programme (ISP) of Uppsala University, Sweden for part financial support.

\section{REFERENCES}

Begum H. A., Yousuf, M.A., Rabbani, K.S. 2016. Effect of top cover material on productivity of solar distillation unit, Bangladesh Journal of Medical Physics, 9, 12-16.

Bendfeld, J., Broker Ch., Menne K., Ortjohann E., Temme L., Vob J. and Carvallo P.C.M., 1998. "Design of a PV- powered reverse osmosis plant for desalination of brackish water", Proceedings of $2^{\text {nd }}$ World Conference and Exhibition on Photovoltaic Solar Energy Conversion, Vienna, Austria, PP. 30753077 .

Islam M.M., Uddin S.A., Islam Z. and Hossain M.I., 2013. "An experimental study on small scale sea water desalination unit through solar power in Cox's Bazar, Bangladesh", Journal of Bangladesh Agricultural University Vol 11(1), PP 165-170.

Khan A., Mojumder S. K., Kovats S., Vineis P., 2008. "Saline contamination of drinking water in Bangladesh", The Lancet, Vol. 371, Issue 9610, page 385.

Rahman M. H., Mamtaz R., Ferdausi S. A., 1997. "Pilot Solar Desalination Plants in Bangladesh", Water and Sanitation for all: Partnerships and Innovations, $23^{\text {rd }}$ WEDC Conference, Durban, South Africa, PP 178-181.

Rahman M. H., Mamtaz R., Rahman M. M., 2001. "Solar Desalination: Experience in Bangladesh", Department of Civil Engineering, BUET, ISES Solar World Congress, PP 1061-1064. 